\title{
Contextualizing the 1997 warm event observed at Patriot Hills in the interior of West Antarctica
}

\author{
Jorge F. Carrasco \\ Centro de Investigación GAIA Antártica, Universidad de Magallanes, Punta Arenas, Chile
}

\begin{abstract}
Between 5 and 8 December 1997, the surface air temperature increased up to $3^{\circ} \mathrm{C}$ in the interior of West Antarctica, at Patriot Hills $(\mathrm{PH})$, located at about $80^{\circ} 08^{\prime} \mathrm{S}, 81^{\circ} 16^{\prime} \mathrm{W}$, at an elevation of $855 \mathrm{~m}$ a.s.l. This was about $15^{\circ} \mathrm{C}$ warmer than the mean air temperature $\left(-12^{\circ} \mathrm{C}\right)$ for this location at this time of the year. The ice surface field along the hills used as a runway for large aircraft melted, forming small ponds at the foot of the slope. This warm event was associated with a passing mid-tropospheric ridge that reached the interior of West Antarctica, whose anticyclonic circulation advected warm air towards the $\mathrm{PH}$ area. The foehn effect of the descending airflow on the northern slope of $\mathrm{PH}$ did not significantly contribute to the warming. The EI Niño-Southern Oscillation (ENSO) was reaching its mature phase during the last quarter of 1997 and the warming/melting episode may be related to large-scale circulation associated with ENSO occurrence. However, warm events in the interior of West Antarctica may occur during any phase of ENSO. In contrast, the negative phase of the Antarctic Oscillation seems to support the development of the mid-tropospheric ridges that can advect warm maritime air towards the interior of West Antarctica. The $3^{\circ} \mathrm{C}$ registered at $\mathrm{PH}$ may be one of the highest near-surface air temperatures measured below $2500 \mathrm{~m}$ a.s.l. in the far interior coastal area of West Antarctica. This suggests a new subregion for determining air temperature records in Antarctica may need to be considered.
\end{abstract}

\section{KEYWORDS}

Air temperature; El Niño-Southern Oscillation; Antarctic Oscillation; ERA-Interim reanalysis; blocking ridge; foehn effect; warm advection

\section{ABBREVIATIONS}

AAO: Antarctic Oscillation; AWS: automatic weather station; CPC-NOAA: Climate Prediction Center, National Center for Environmental Prediction, National Oceanic and Atmospheric

Administration (USA); ENSO:

El Niño-Southern

Oscillation; ERAin:

ERA-Interim database; PH: Patriot Hills; PHC: Patriot Hills camp; SD: standard deviation; $\mathrm{t} 2 \mathrm{~m}$ : air temperature at $2 \mathrm{~m}$ above the surface

\section{Introduction}

Recently, Nicolas et al. (2017) described an intense melt event that took place when near-surface air temperature was $0^{\circ} \mathrm{C}$ or above during $10-$ 21 January 2016, affecting large portion of the Ross Ice Shelf. A main factor associated with this event was the presence of a blocking high over the Southern Ocean, north of the Amundsen Sea. The ridge configuration suggests strong north-south advection of warm marine air towards the Ross Ice Shelf region, crossing Marie Byrd Land and travelling a distance of about $1500 \mathrm{~km}$. This event took place during the strong El Niño of 2015-16, which may be responsible for the warm event; however, no conclusive connection between the event and El Niño was found (Nicolas et al. 2017). Another unusual warm event occurred at the northern tip of the Antarctic Peninsula, where the Argentine Esperanza Base registered a record high temperature of $17.5^{\circ} \mathrm{C}$ on 24 March 2015; this occurred one day after the Argentine Marambio Base had registered $17.4^{\circ} \mathrm{C}$ (Skansi et al. 2017).
This time, a mid-latitude tropospheric ridge extended southward, reaching the northern Antarctic Peninsula on 23 March. This ridge pattern caused warm advection towards the area and westerly winds towards the mountain range, causing foehn winds in the lee of the mountains and thereby contributing to an increase of the air temperature on the eastern slope of the peninsula (Boskurt et al. 2018). Skansi et al. (2017) indicated that the highest extreme temperature recorded south of latitude $60^{\circ} \mathrm{S}$ is $19.8^{\circ} \mathrm{C}$ and occurred on 30 January 1982 at Signy Island $\left(60^{\circ} 43^{\prime} \mathrm{S} 45^{\circ} 36^{\prime} \mathrm{W}\right)$, located to the north-east of the northern tip of the Antarctic Peninsula (around $650 \mathrm{~km}$ from Esperanza Base). Once again, a tropospheric ridge was passing over the region advecting warm air and generating foehn winds on the lee side of the South Orkney Islands, where the weather station was located (Skansi et al. 2017). As Skansi et al. (2017) mentioned, a World Meteorological Organization committee recommended two subregions for establishing extreme temperature records southward of $60^{\circ} \mathrm{S}$. One is the Antarctic continent 
and all islands immediately adjacent to it (which excludes Signy Island), and the other is all regions above $2500 \mathrm{~m}$ a.s.l., which includes mostly East Antarctica. Thus, the temperature recorded at Esperanza Base became the highest ever recorded on the Antarctic continent since instrumental measurements. On the other hand, the highest temperature measured within the Antarctic subregion above $2500 \mathrm{~m}$ a.s.l. is $-7^{\circ} \mathrm{C}$, recorded by an AWS at D-80 (70 ${ }^{\circ} 6^{\prime} \mathrm{S}, \quad 134^{\circ} 53^{\prime} \mathrm{E}, \quad 2500 \mathrm{~m}$ a.s.l. $)$ on 28 December 1989 (Skansi et al. 2017). The 500$\mathrm{hPa}$ field for this day resolved a tropospheric ridge whose axis was just to the west of the station. Warm air advection circulated counter-clockwise towards the D-80 AWS and contributed to the increased air temperature.

In between the coastal areas of the Antarctic continent and the adjacent islands, where extreme air temperature can reach far above $0^{\circ} \mathrm{C}$, and the subregion above $2500 \mathrm{~m}$ a.s.l., where surface temperature is not likely to rise above $0^{\circ} \mathrm{C}$; there is an extensive region where the near-surface air temperature can exceed $0^{\circ} \mathrm{C}$ (and cause a melting event), but is not likely to be as high as in the near coastal areas. A case of extreme air temperature above $0^{\circ} \mathrm{C}$ was registered in the interior of West Antarctica at $\mathrm{PH}$, when the air temperature reached $3^{\circ} \mathrm{C}$ at 14 UTC on 7 December 1997. Here, a description of this event is presented, as well as an analysis about whether this kind of event has occurred on other occasions and its possible relation with ENSO.

\section{Geographical location of PH and data availability}

$\mathrm{PH}$ is located at the southern end of the Ellsworth Mountains, in the interior of West Antarctica $\left(80^{\circ} 08^{\prime} \mathrm{S}\right.$, $81^{\circ} 16^{\prime} \mathrm{W}, 855 \mathrm{~m}$ a.s.l.; Fig. 1). $\mathrm{PH}$ is a chain of hills $8 \mathrm{~km}$ in length and about $400 \mathrm{~m}$ above the ice/snow surface, with the highest summit at $1246 \mathrm{~m}$ a.s.l.. More than $1000 \mathrm{~km}$ separate PH from the nearest open Southern Ocean areas. The grounding line that limits the ice sheet and the Ronne/Filchner Ice Shelf is about $50 \mathrm{~km}$ north-east of $\mathrm{PH}$. Along the northern side of $\mathrm{PH}$, a bare ice surface, $4 \mathrm{~km}$ by $2 \mathrm{~km}$, known as a blue ice area (Bintanja 1999), was used as a runway for wheeled C-130 aircraft (Swithinbank 1987). About $3000 \mathrm{~m}$ to the north of PH (Fig. 1), the Chilean Air Force and the Chilean Antarctic Institute deployed a temporary research camp (PHC) to carry out scientific fieldwork (see, for example, Casassa et al. 1998) between 17 November and 16 December 1997.

The instrumentation at PHC consisted of mercury thermometers for maximum and hourly readings, an alcohol-in-glass thermometer for minimum readings and a thermograph. These were installed at the camp at $1.5 \mathrm{~m}$ above the snow surface inside an instrument weather shelter. The shelter protected the instruments from direct and indirect solar radiation, while at the same time allowing adequate ventilation. An aneroid barometer and a barograph were set up for pressure reading and recording. A portable anemometer was used to measure wind speed and wind direction at the camp. At least three-hourly observations were carried out from 21 November to 15 December. These included, surface

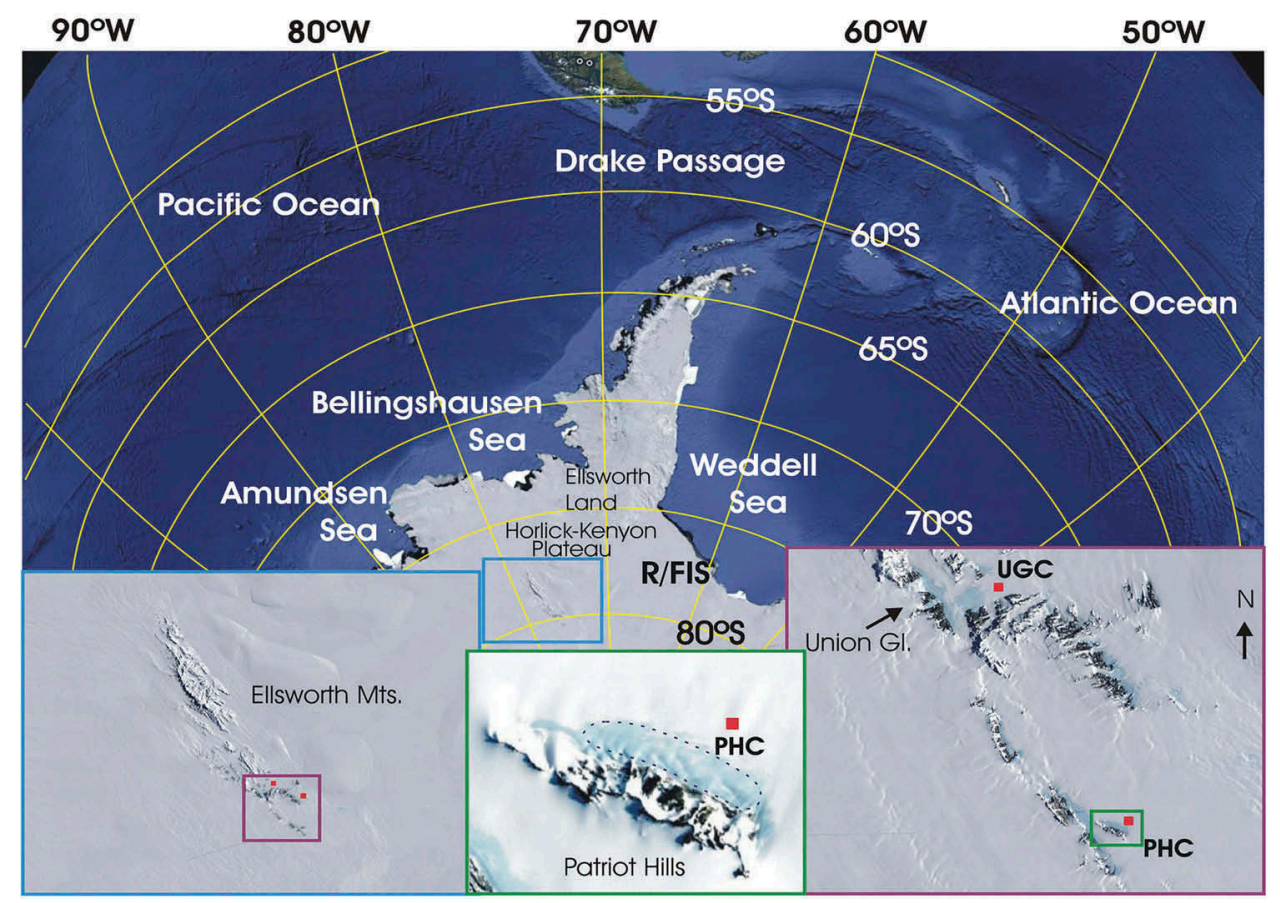

Figure 1. Location map. R/FIS: Ronne/Fitchner Ice Shelf, UGC: Union Glacier Camp. 


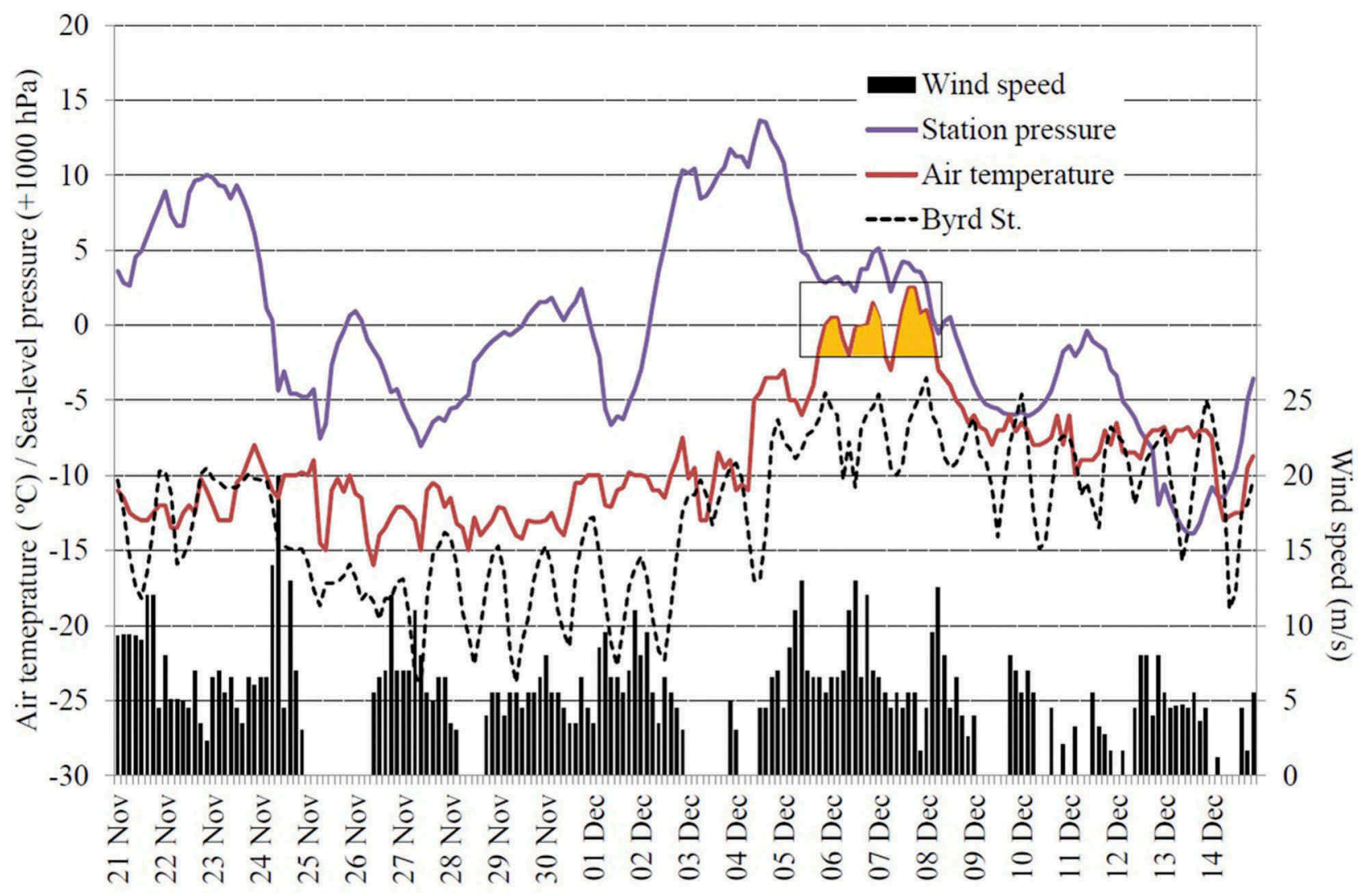

Figure 2. Three-hourly air temperatures, sea-level pressure and wind speed measurement taken at Patriot Hills between 21 November and 15 December 1997. Orange shading highlights temperatures above $-2{ }^{\circ} \mathrm{C}$ (surface melting can occur belowfreezing near-surface air temperature because of radiative heating). The dashed curve is the air temperature measured at Byrd Station.

Table 1. Prevailing daily weather conditions registered at PH during 21 November to 14 December 1997.

\begin{tabular}{|c|c|c|c|c|c|c|}
\hline \multirow{2}{*}{$\begin{array}{l}\text { Date } \\
1997\end{array}$} & \multirow[b]{2}{*}{ Daily wind means $(\mathrm{m} / \mathrm{s})$} & \multirow{2}{*}{$\begin{array}{l}\text { Windshield } \\
\text { daily means }\end{array}$} & \multicolumn{2}{|c|}{ Temperature } & \multirow[b]{2}{*}{ Cloudiness $^{\mathrm{a}}$} & \multirow[b]{2}{*}{ Significant weather condition } \\
\hline & & & $\min$. & $\max$. & & \\
\hline 21 Nov. & 9.4 & -22.9 & -14 & -12 & SKC & Blizzard/-SN \\
\hline 22 & 5.1 & -20.0 & -15 & -10.5 & SKC & \\
\hline 23 & 5.8 & -18.3 & -13.5 & -8.5 & SCT & \\
\hline 24 & 9.3 & -19.6 & -11 & -9 & $\mathrm{SCT}$ & \\
\hline 25 & 0 & 6.1 & -15 & -10 & $\mathrm{SKC} \rightarrow \mathrm{BKN}$ & \\
\hline 26 & 4.8 & -12.8 & -15.5 & -11 & SCT & \\
\hline 27 & 7.1 & -21.5 & -15.1 & -10.5 & SKC & \\
\hline 28 & 2 & -7.7 & -17.2 & -12.8 & $\mathrm{SKC} \rightarrow \mathrm{BKN}$ & \\
\hline 29 & 5.3 & -21.6 & -14.8 & -12.5 & $\mathrm{OVC} \rightarrow \mathrm{BKN}$ & \\
\hline 30 & 5.2 & -20.1 & -15.5 & -10.5 & OVC & \\
\hline 1 Dec. & 7.3 & -19.7 & -11.5 & -9.5 & $\mathrm{BKN} \rightarrow \mathrm{SKC}$ & $-\mathrm{SN}$ \\
\hline 2 & 5.8 & -17.8 & -11.8 & -7.8 & SKC & \\
\hline 3 & 0.6 & 3.7 & -13.5 & -13 & $\mathrm{BKN} \rightarrow \mathrm{SKC}$ & \\
\hline 4 & 3.2 & -4.2 & -13 & -2 & SKC & \\
\hline 5 & 7.8 & -10.9 & -7 & 2.1 & SKC & \\
\hline 6 & 8.7 & -6.6 & -2.5 & 1 & $\mathrm{SCT} \rightarrow \mathrm{BKN}$ & \\
\hline 7 & 4.9 & -4.5 & -4 & 3 & SKC & \\
\hline 8 & 6.5 & -9.7 & -6.5 & 1 & BKN & \\
\hline 9 & 2.4 & 0.3 & -7.1 & -6 & $\mathrm{SCT} \rightarrow \mathrm{BKN}$ & \\
\hline 10 & 3.1 & -5.5 & -7.8 & -5 & SKC & \\
\hline 11 & 2.0 & -5.6 & -10 & -6 & SKC & \\
\hline 12 & 4.3 & -9.0 & -8.9 & -6.5 & $\mathrm{SKC} \rightarrow \mathrm{BKN}$ & \\
\hline 13 & 4.7 & -13.6 & -9.8 & -6.8 & $\mathrm{SCT} \rightarrow \mathrm{BKN}$ & \\
\hline 14 & 1.6 & -4.9 & -13 & -7.5 & BKN & \\
\hline
\end{tabular}

${ }^{a}$ SKC: $\leq 1$ octas, SCT: $\leq 4$ octas, BKN: $5 \geq$ and $\leq 7$ octas, OVC: 8 octas. ${ }^{\text {b}}-$ SN is weak snowfall.

air temperature, visibility, wind, station pressure, cloud conditions and significant weather phenomena.

In situ and reanalysis data obtained from the ERAin (Dee et al. 2011) accessed via the Climate Explorer website (http://climexp.knmi.nl/start.cgi) and the European Centre for Medium-Range Weather Forecasts website (http://apps.ecmwf.int/datasets/ data/interim-full-daily) were used for this study. 


\section{In situ observations of the 1997 warm event at $\mathrm{PH}$}

Figure 2 shows the three-hourly air temperature measurements taken with the mercury thermometer at PHC, along with the sea-level pressure and wind speed. Table 1 summarizes the daily means weather condition that prevailed during the 21 November14 December 1997 campaign. The prevailing wind direction was south-south-westerly, of katabatic origin (Carrasco 1999). From 17 November until 4 December the air surface temperatures fluctuated between $-16^{\circ} \mathrm{C}$ and $-7^{\circ} \mathrm{C}$, which were comparable to those observed for similar periods during the two previous campaigns in 1996 and 1995 (Carrasco 1996, 1997). The air temperature then increased, reaching a maximum of $3^{\circ} \mathrm{C}$ at 14 UTC on 7 December; this is on average, about $15^{\circ} \mathrm{C}$ degrees warmer than the early December average (which is about $-12^{\circ} \mathrm{C}$ ), determined from records obtained in similar periods during previous campaigns. During 8 and 9 December, the air temperature rapidly decreased, fluctuating between $-13^{\circ} \mathrm{C}$ and $-6^{\circ} \mathrm{C}$ from 9 to 15 December (Fig. 2). For 34 h, the air temperature was above $0^{\circ} \mathrm{C}$. Figure 2 also shows the air temperature behaviour at Byrd station $\left(80^{\circ} \mathrm{S}\right.$, $119.5^{\circ} \mathrm{W}, 1530 \mathrm{~m}$ a.s.l.), revealing a concurrent warm episode at this location and indicating the regional extension of the event.

Melting processes occur with surface temperature equal or greater than $0^{\circ} \mathrm{C}$ and positive surface energy budget (Senese et al. 2014). However, most of the time, what is available is the air temperature measured at 1.5 or $2 \mathrm{~m}$ above the surface. In these cases, empirical relationships have been proposed between air temperature and snow/ice melting (i.e., $T$-index, degreeday models; see Senese et al. 2014 and references therein). Though a thorough consideration of this phenomenon is beyond the scope of this study, it can be mentioned that Senese et al. (2014) found snow melting with daily average air temperature of -2.6 and minimum of $-4.6^{\circ} \mathrm{C}$ on alpine glaciers, and van den Broeke et al. (2010) found a threshold of $-5^{\circ} \mathrm{C}$ in south-west Greenland. Hoffman et al. (2008) indicated an average air temperature of $-2.5^{\circ} \mathrm{C}$ at Taylor Glacier in the McMurdo Dry Valleys sector. A threshold of $-2^{\circ} \mathrm{C}$, mentioned by, was used for counting the time that the Taylor Glacier snow/ice surface was exposed to melting (Nicolas et al. 2017); however, the actual melting hours most likely occurred during the maximum radiative warming (Bennartz et al. 2012). Air temperature above $-2^{\circ} \mathrm{C}$ at $\mathrm{PHC}$ started at 18 UTC 5 December and ended at 3 UTC 8 December, giving an event duration of 57 hours. This is considered the "likely melting period" that took place at $\mathrm{PH}$, which includes three periods of nine, 10 and $15 \mathrm{~h}$ (total of 34 h) with air temperatures above $0^{\circ} \mathrm{C}$ (Table 2), most probably coinciding with the daily maximum radiative warmings (see Fig. 2).

One of the first effects of the warming (5 December) was that the top ca. $10-15 \mathrm{~cm}$ of the snow became softer compared to previous days. The blue ice surface also started to melt, forming a thin layer of water that made walking without crampons slippery. At the foot of the northern face of $\mathrm{PH}$, near a moraine area, the surface ice melted, forming a small pond of about $2500-3000 \mathrm{~m}^{2}$ (Fig. 3). It was now evident that the shape of the ice surface in this area was moulded by periods of melting.

The daily average wind speed during the event was $5 \mathrm{~m} \mathrm{~s}^{-1}$, with a minimum on 3 December $\left(1.2 \mathrm{~m} \mathrm{~s}^{-1}\right)$ and a maximum on 6 December $\left(8.8 \mathrm{~m} \mathrm{~s}^{-1}\right)$. Southsouth-westerly (ca. $200^{\circ}$ geographic north) was the predominant direction of the wind; this is almost perpendicular to the orientation of the $\mathrm{PH}$; therefore, the observational site was on the downwind (lee) side of the hills.

Just before the rise of the air temperature, an increase in the atmospheric pressure took place from 1 to 4 December. The station pressure recorded at PHC increased from $897 \mathrm{hPa}$ (ca. $993.2 \mathrm{hPa}$ at sea-level pressure) on 1 December to $912.8 \mathrm{hPa}$ (ca. $1013.5 \mathrm{hPa}$ at sea-level pressure) on 4 December, decreasing thereafter. The pressure is near $16 \mathrm{hPa}$ higher than the average period of previous days (24 November1 December). Similar pressure behaviour was registered by all stations located in the Antarctic Peninsula. However, the warm event at $\mathrm{PH}$ was not registered by the Chilean Antarctic stations Prat, Ohiggins, Frei and Carvajal, located at the northern tip of the Antarctic Peninsula and on its west side. Even though the actual values of the air temperatures showed an increase during the first week of December, the anomalies with respect to their monthly average were within the normal

Table 2. Warm events registered by the AWS located at PH (2008-2011) and Glacier Union (2011-present). Included is the event occurred in 1997.

\begin{tabular}{lccc}
\hline & Duration & Duration \\
Warm events & $\mathrm{T}_{\text {air }}>0^{\circ} \mathrm{C}$ (hours) & $\mathrm{T}_{\text {air }}>-2^{\circ} \mathrm{C}$ (hours) & 57 \\
\hline 5-8 January 1997 & 34 & 58 & 3.0 \\
15 January 2010 & 11 & 55 & 0.4 \\
29-31 December 2012 & 14 & 142 & 1.7 \\
13-18 January 2013 & 12 & 22 & 1.5 \\
21-22 February 2013 & 12 & 29 & 3.3 \\
11-12 January 2016 & 2 & 0.3 \\
\hline
\end{tabular}




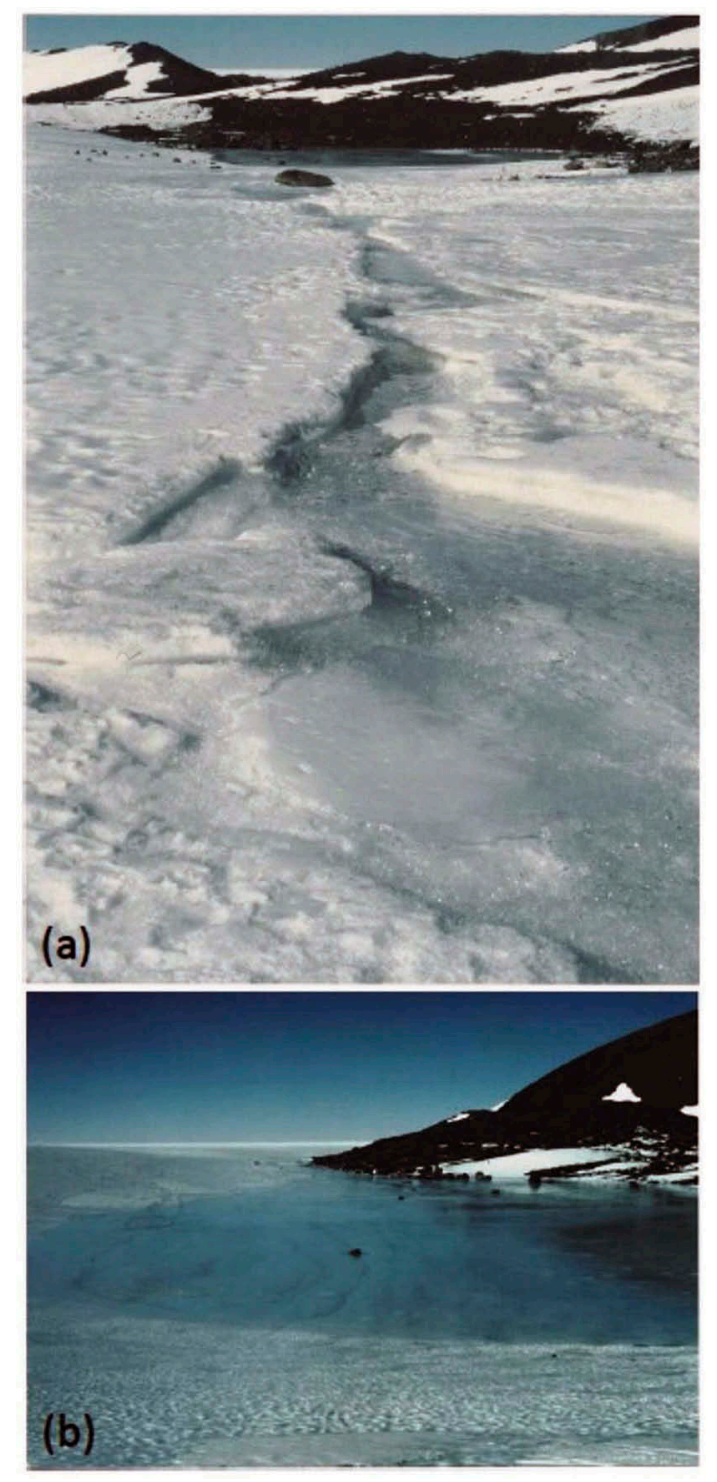

Figure 3. (a) Snow/ice melting and (b) small pond at PH on 5 December 1997 (photographs by Dr Gino Casassa).

variability and only statistically different at Prat Station during the days of the event.

\section{Analysis of the 1997 warm event at PH}

Figures 4 and 5 show ERAin sea-level pressure and 500 $\mathrm{hPa}$ fields, respectively (a, c, e, g), and the corresponding anomalies $(b, d, f, h)$ averaged every three days from 28 November to 9 December 1997. The anomalies were calculated using the 1980-2010 period. The surface analysis (Fig. 4) resolved a cyclonic circulation in the southern polar ocean to the north of Amundsen Sea, which weakened after 1 December. At the same time, a ridge started to develop over the Antarctic Peninsula with a high-pressure system centred just east of Drake Passage to the north-east of the peninsula. Statistically significant (95\%) positive anomalies over the Antarctic Peninsula and the interior of West Antarctica (HollickKenyon Plateau) prevailed during 1 to 6 December.
The 500-hPa analyses also resolved a ridge over the Antarctic Peninsula that extended towards West Antarctica (Fig. 5c, d). The magnitude and intensity of the ridge is indicated by the corresponding anomaly fields (Figs. 4d, f, 5d, f), which are statistically significant at the $95 \%$ confidence level in the ridge area. This trough-ridge-trough pattern prevailed between 1 and 8 December. The associated anticyclonic synoptic-scale circulation advected warm maritime air from the Bellingshausen Sea towards West Antarctica, passing by the Hollick-Kenyon Plateau, Byrd Station and the vicinity of PH. The ridge started to develop on 30 November and weakened after 9 December. Its maximum intensity and amplitude took place on 3 and 4 December, respectively, but the synoptic-scale pattern maintained the warm advection towards $\mathrm{PH}$ area until 7 December.

Along with this synoptic scale environment, it is necessary to analyse the role of boundary layer processes around PHC, which is characterized by blue ice. One local feature to consider is the foehn effect. Speirs et al. (2013) and Steinhoff et al. (2013) studied the foehn winds in the McMurdo Dry Valley and they found that foehn wind can cause an increase air temperature to above freezing, which can result in intensive melting. Foehn winds occur in the lee side of a mountain (or hill) barrier, where the downward airflow adiabatically warms and dries. They can affect landscape forming processes like glacial melting, streamflow and rock weathering (Speirs et al. 2013). The downslope airflow that affects the blue ice field and PHC mainly comes from the interior of East Antarctica (see Parish \& Bromwich 1987), descending more than $2000 \mathrm{~m}$ before reaching the area. Moreover, $\mathrm{PH}$ has an elevation of about $400 \mathrm{~m}$ above the blue ice and it has an almost perpendicular orientation to the persistent large-scale downslope airflow (of katabatic origin, but in summer most probably responding also to meso- and synopticscale circulation [Parish \& Cassano 2003]). Therefore, it is reasonable to suspect that adiabatically warmed downslope winds could also contribute to the observed warm episode. Speirs et al. (2013) and Steinhoff et al. (2013) found that the foehn events in the Dry Valleys were associated with increased wind speed, with a wind direction that is more perpendicular to the topographic barrier (south-westerly in that case), decreased relative humidity and increased air temperature. In the case presented here, even though there was an increase of the wind speed during the warming event, similar previous increases were not accompanied by increasing air temperature. The prevailing wind was south-southwesterly and during the event slightly veered towards a more south-westerly direction, and the relative humidity did not show a decrease with respect the average behaviour (Fig. 6a, c). Therefore, the observed weather behaviour at PHC suggests that the warming was not forced by the foehn effect, or at least, its contribution was not relevant. 

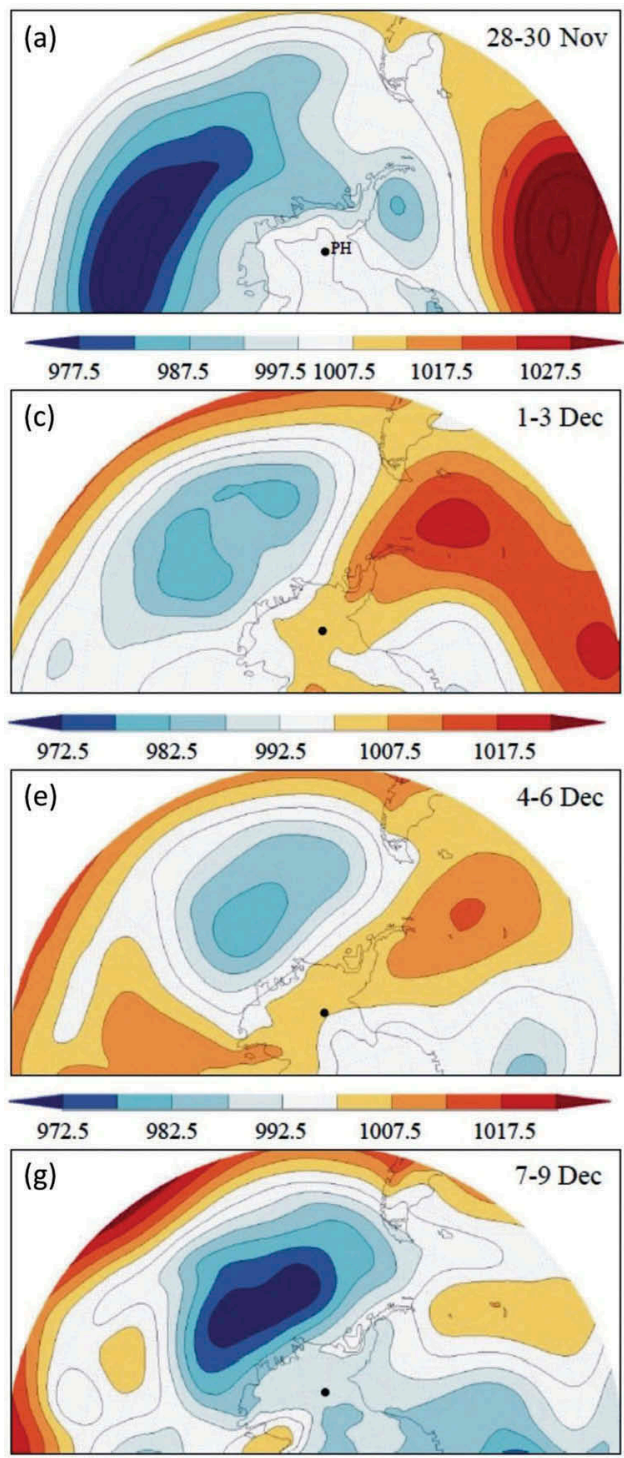

$987990993996999 \quad 100510081011 \quad 10141017$
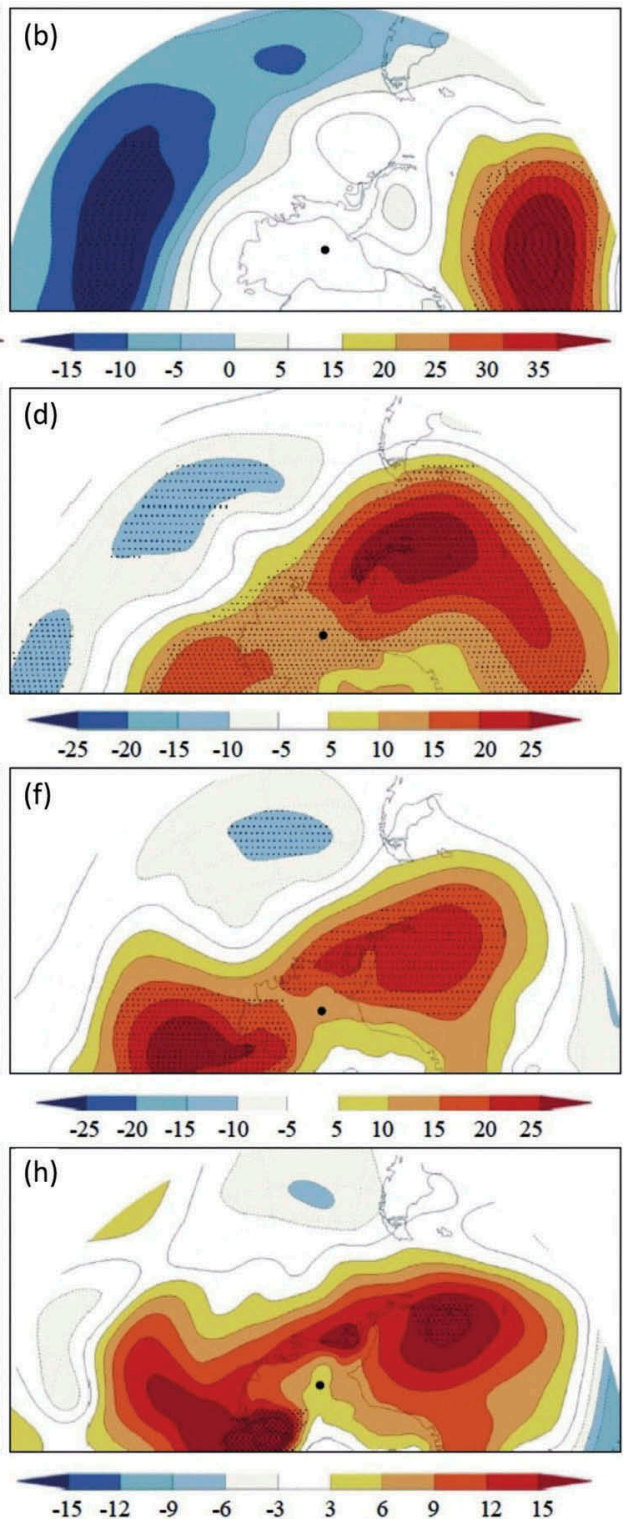

Figure 4. Sea-level pressure charts averaged every three days (left) and the corresponding anomalies (right). Shaded areas are regions where the anomalies are statistically significant at the $95 \%$ confidence level. The black dot represents the location of $\mathrm{PH}$.

As mentioned, the synoptic-scale analysis indicates that the circulation associated with a tropospheric ridge advected warm maritime air from the Bellingshausen Sea towards the vicinity of PH. Figure 7 show ERAin near-surface air temperature and wind direction and speed at 00 UTC from 4 to 7 December. The air temperature increased from 4 to 7 December by about $8^{\circ} \mathrm{C}$ in the simulated field. This warming occurred with westerlysouth-westerly airflow over $\mathrm{PH}$. The $850 \mathrm{hPa}$ (not shown) suggests that during this period the ridge axis was located to the north of $\mathrm{PH}$ supporting the westerly-south-westerly winds. According with the concurrent air temperature at South Pole (Clean Air) and Byrd Station, adiabatic warming of descending air towards $\mathrm{PH}$ can reach around $9{ }^{\circ} \mathrm{C}$ per $1000 \mathrm{~m}$. This means that the foehn effect of the descending airflow in $\mathrm{PH}$ could contribute to the warming by about $3-4{ }^{\circ} \mathrm{C}$.
Comparing the observed and ERAin simulated air temperatures indicates that the model has a cold bias of $-0.96 \pm 1.76$ ( $1 \mathrm{SD}$ ) given mainly by the simulations at 06 and 12 UTC. Taking this in consideration, the observed warming event was above the $97.5 \%$ percentile of the corresponding daily distribution in the ERAin t2m time series (19792016 period). This suggests that the event can be classified as an extreme warm event. The ERAin simulated the overall warm episode (Fig. 6a) but with a cold bias of ca. $2.7^{\circ} \mathrm{C}$ and cooling after 8 December that was more gradual than observed. The simulated wind speed did not resemble the observed behaviour, although an increase was resolved that coincides with the initial warming (Fig. 6b). ERAin simulated westerly-south-westerly winds $\left(260^{\circ}\right)$ during the campaign, with significant discrepancies with observed airflow (Fig. 6c). Also, the model did not resolve the actual behaviour of 

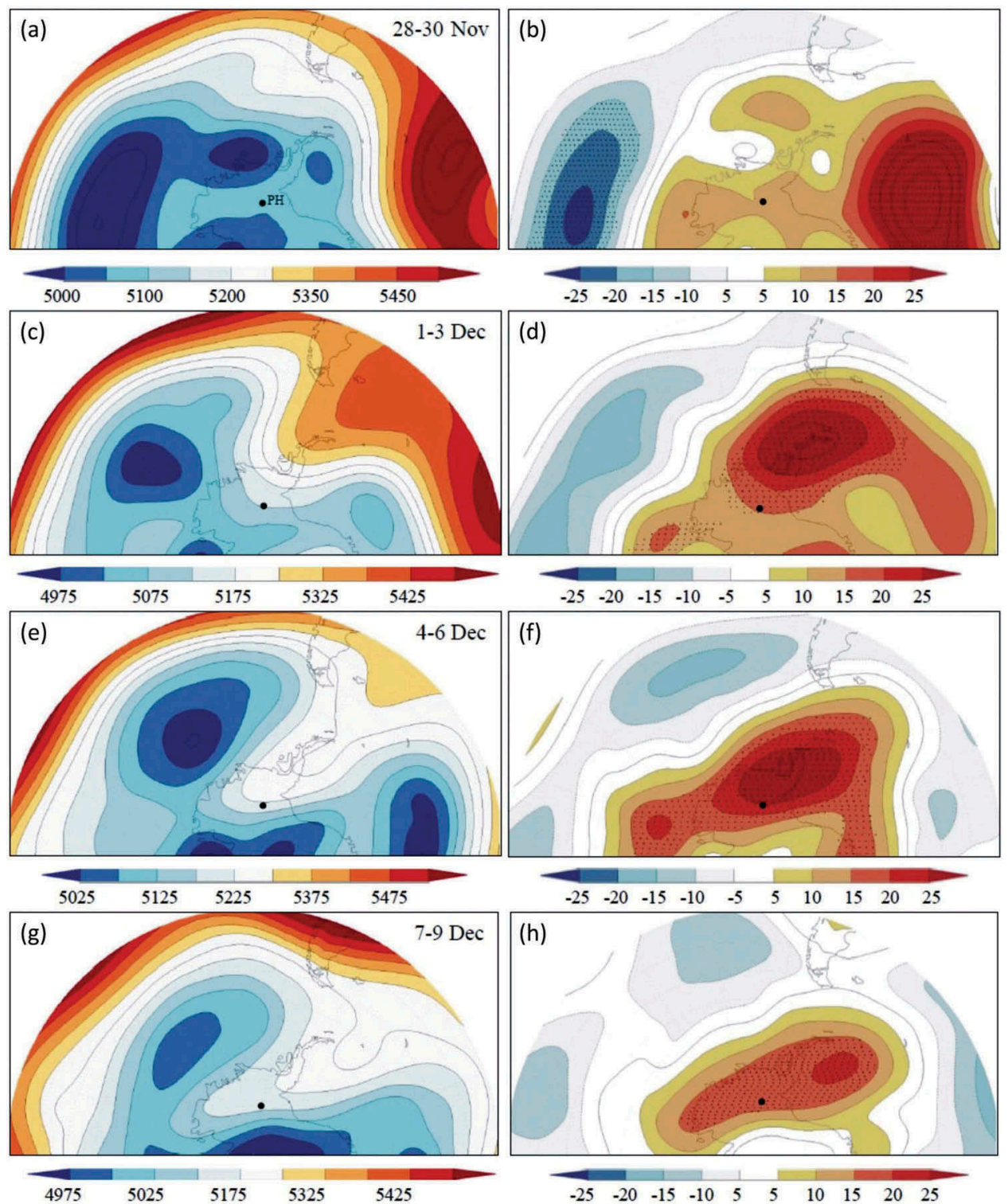

Figure 5. Analyses at $500 \mathrm{hPa}$ (in gpm) averaged every three days (left) and the corresponding anomalies (right). Shaded areas are regions where the anomalies are statistically significant at the $95 \%$ confidence level. The black dot represents the location of $\mathrm{PH}$.

the relative humidity (Fig. 6d), and it did not show a decrease during the warm event. Therefore, the observed and the ERAin simulated weather indicate that foehn type warming is not relevant for the event that was observed at PHC.

\section{Additional warm events at PH}

Hourly air temperatures recorded by an AWS operated by the Antarctic Network International Company at $\mathrm{PH}$ and later by the Antarctic Logistic \& Expedition at Union Glacier $\left(79.76^{\circ} \mathrm{S}, 83.27^{\circ} \mathrm{W}\right.$, $767 \mathrm{~m}$ a.s.l.), allow to extend the observed analysis from 2008 to 2016 . Five more events above $0^{\circ} \mathrm{C}$ are revealed by the temperature record (Table 2). The last event coincides with the melting episode described by Nicolas et al. (2017), observed in the Ross Sea sector of the West Antarctic Ice Sheet in January 2016. Also, one of the warm events registered a record temperature for the area of $3.3^{\circ} \mathrm{C}$ at 21 UTC 21 February 2013, which took place at Union Glacier, located about $68 \mathrm{~km}$ to the west of $\mathrm{PH}$. None of these events was captured by the $500-\mathrm{hPa}$ three-day criteria (see below for this definition), including the January 2016. For the 2122 February 2013 event, only 21 February showed a gpm anomaly above 2 SD. Individual examination of the synoptic-scale fields associated with these events revealed the presence of a passing ridge over Ellsworth Land. Only for the event that occurred in 2010 does the synoptic-scale analysis show a lowpressure centre located just to the west of the northern tip of the Antarctica Peninsula. This cyclonic circulation over the peninsula advects relatively warmer air from the Weddell Sea towards southern Ellsworth Land. 


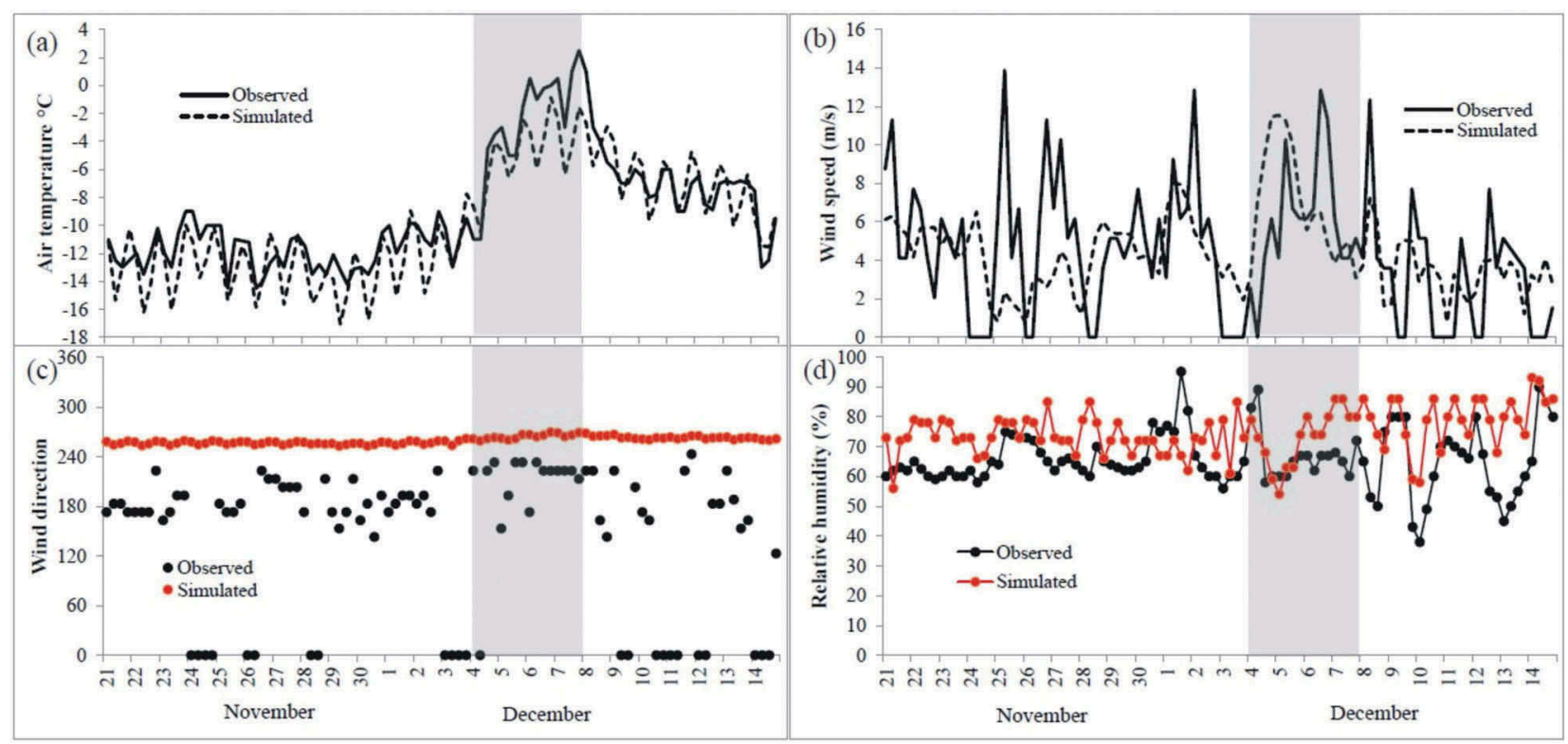

Figure 6. Near-surface air temperature, wind speed, wind direction and relative humidity registered in situ during the campaign at PHC (black) and concurring simulated variables by the ERA-Interim model at the nearest gridpoint (red).

To investigate the frequency of warm events, which are associated with the development of a tropospheric ridge in the Southern Ocean, additional 500-hPa geopotential height analyses are presented here. First, the $500 \mathrm{hPa}$ height pattern observed during the warm event that occurred during 5 and 7 December 1997 indicates that the simulated geopotential height at 500 $\mathrm{hPa}$ around $\mathrm{PH}$ was 190 geopotential $\mathrm{m}$ (gpm) above the average for three consecutive days. This is a greater than 2.0 SD anomaly, i.e., these geopotential anomalies can be classified as an extreme gpm accompanying a warm event (within the $5 \%$ confidence level considering a normal distribution). A gridpoint near $\mathrm{PH}$ (cutting out the region with longitude $=279.492 /$ 280.195 and latitude $=-80.701 /-79.999)$ was selected for analysing the daily $500 \mathrm{hPa}$ ERAin data for the 1979-2016 period. The time series of the geopotential heights at $500 \mathrm{hPa}$ allow identification of similar behaviour to that observed during the 5-7 December 1997, i.e., periods of at least three consecutive days with geopotential heights above the corresponding 2.0 SD. To determine these extreme values, climatological multiyear daily averages and 2.0 SD were first calculated using as a baseline the 1981-2010 period, where the seasonal cycle was removed from the anomalies. Then, the daily simulated geopotential height anomalies for each year were compared with the corresponding 2.0 SD. This gives us a series of days with geopotential heights above the threshold given by the daily $2.0 \mathrm{SD}$. These periods were defined as extreme positive gpm events. Figure 8 shows the number of events that met this criterion, a total of 47 events occurred during the 1979-2016 period, ranging from one to four events per year, but 15 years (out of 38 years) did not registered any event.

The composite mean and anomalies field of sealevel pressure and $500 \mathrm{hPa}$ analyses (Fig. 9) for the extreme positive gpm events near $\mathrm{PH}$ were constructed using ERAin data. A blocking ridge configuration is clearly depicted over the Antarctic Peninsula, with significant positive anomalies around $72^{\circ} \mathrm{S}, 70^{\circ} \mathrm{W}$ for sea-level pressure and around $76^{\circ} \mathrm{S}$, $74^{\circ} \mathrm{W}$ for $500 \mathrm{hPa}$. This pattern suggests warm advection towards Ellsworth Land, in the interior of West Antarctica, that can eventually reach the $\mathrm{PH}$ area. However, not all the warm advection increases the air temperature in the interior of West Antarctica above $0^{\circ} \mathrm{C}$. The atmospheric anticyclonic circulation near the surface could also support the south-westerly downslope airflow, which can adiabatically warm the air by the foehn effect while descending the northern slope (lee side) of $\mathrm{PH}$.

\section{Discussion}

ENSO is an important mode of inter-annual variability whose genesis is in the tropical Pacific Ocean but has global impacts. It is a coupled oceanic-atmospheric phenomenon that appears, on average, every four to seven years (Renwick 1998). Several studies have been suggesting that sensitive parameters like air temperature and sea-ice extent can be affected by the changes in the atmospheric circulation associated with ENSO in the southern polar region (e.g., Turner 2004; Yuan 2004). Here, the warming event 

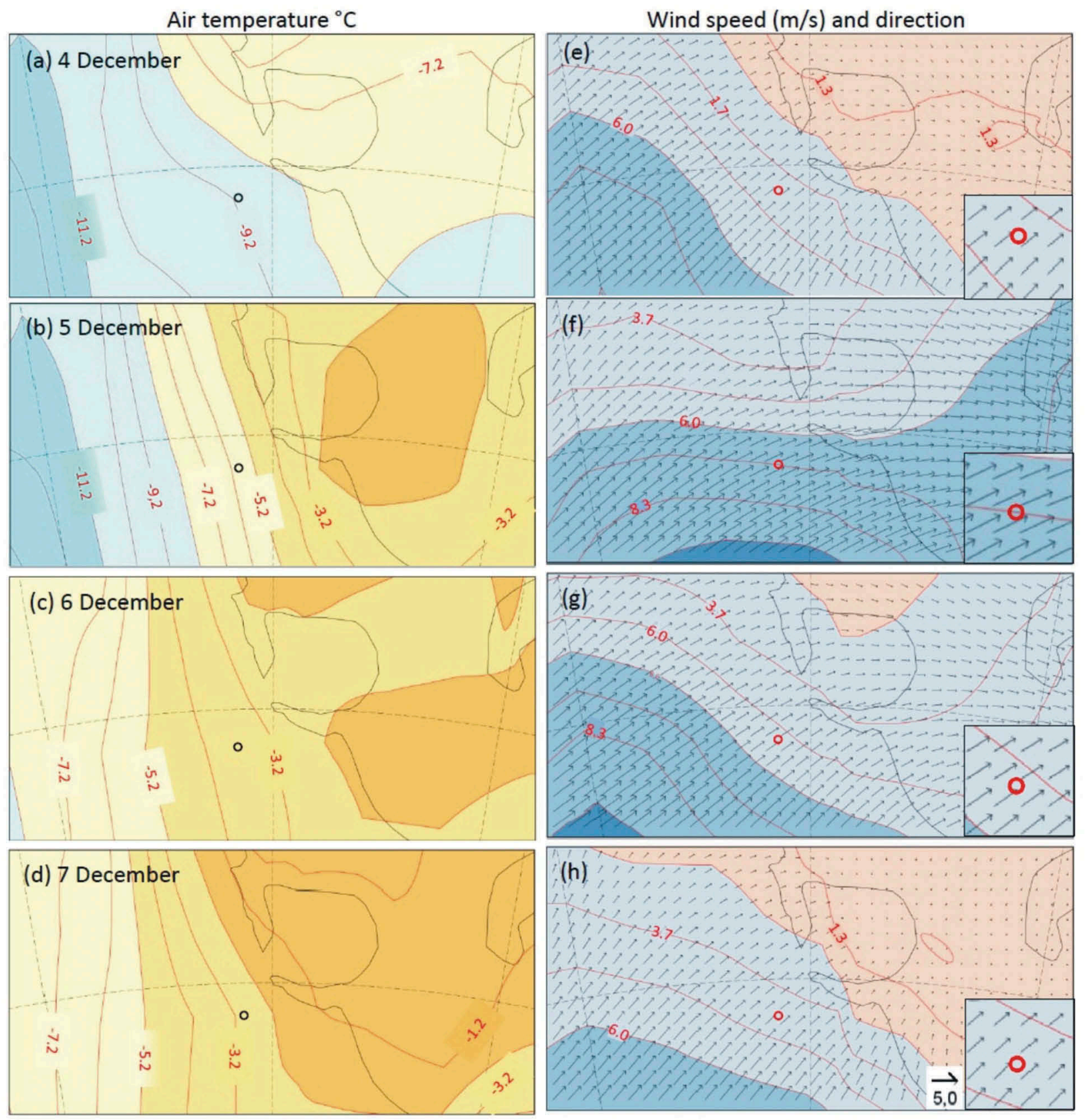

$\begin{array}{llllllllllllllll}-23.2 & -21.2 & -19.2 & -17.2 & -15.2 & -13.2 & -11.2 & -9.2 & -7.2 & -5.2 & -3.2 & -1.2 & 0.9 & 2.9 & 4.9 & 6.9\end{array}$

$\begin{array}{lllllllllllllllll}-15.0 & -12.7 & -10.3 & -8.0 & -5.7 & -3.3 & -1.0 & 1.3 & 3.7 & 6.0 & 8.3 & 10.7 & 13.0 & 15.3 & 17.7 & 20.0 & \overrightarrow{5.0}\end{array}$

Figure 7. Near-surface air temperature (left) and wind speed (right) fields at 00 UTC from 4 to 7 December 1997. Black/red circle is the location of $\mathrm{PH}$. Right panels include a close-up of the wind field near $\mathrm{PH}$.

observed in the interior of West Antarctica occurred during the mature phase of the 1997-1998 El Niño, the strongest event during the 20th century.

The warm events identified in the previous section were characterized according with the prevailing ENSO phase. For this, warm, cold and neutral episodes were obtained using the Oceanic Niño Index (Huang et al. 2017) provided by CPC-NOAA. Comparison of the extreme warm events with ENSO phase show that nine years with events (24\%) occurred with El Niño episodes while five years (13\%) occurred with La Niña events and nine years (24\%) occurred with neutral ENSO conditions (Fig. 8).
ERAin surface temperature data can also be used to assess how often extreme warm events occur during El Niño. The near-surface air temperature simulated by the ERAin reanalysis is, on average, $1.5 \pm 1.2(1 \mathrm{SD})$ degrees $\mathrm{C}$ colder than observed based on a comparison of the daily mean of the observed data registered during the 1995, 1996 and 1997 campaigns. The ERAin simulated air temperature ranged $\mathrm{C}$ from -3.8 to $-4.2{ }^{\circ} \mathrm{C}$ during the warm event that took place from 5 to 7 December 1997. Considering only the extreme gpm events that occurred with near-surface air temperature equal to that simulated in ERAin 


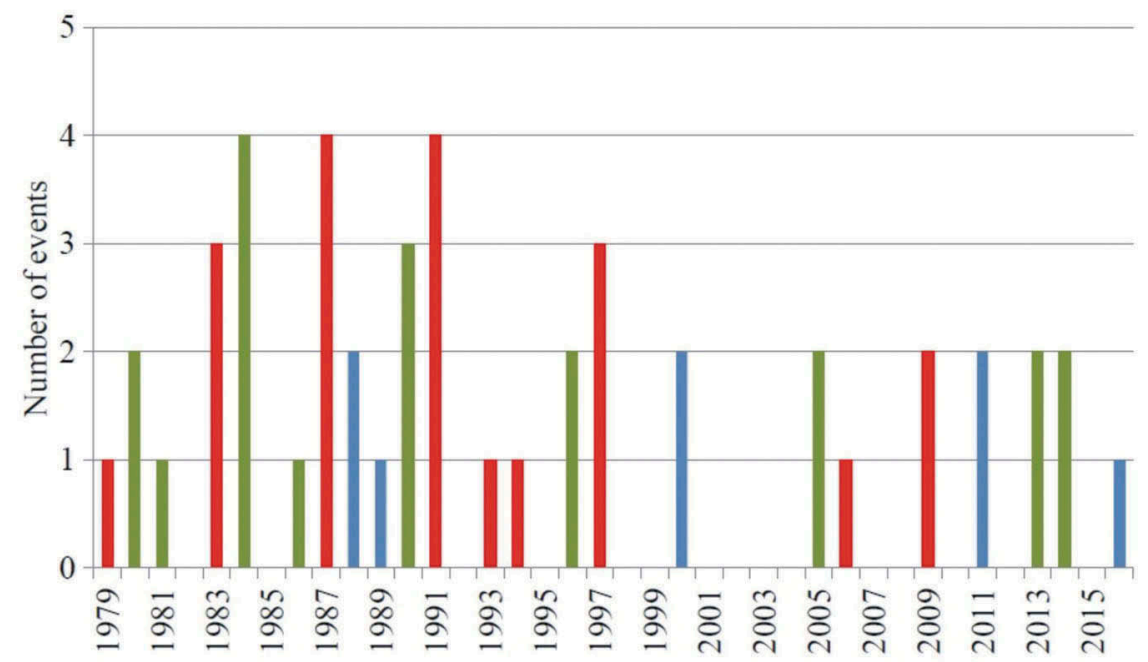

Figure 8. Annual number of extreme warm events (those whose geopotential anomalies at $500 \mathrm{hPa}$ were above the $2.0 \mathrm{SD}$ at the nearest gridpoint from PH) during the 1979-2016 period, obtained from ERAin. Red identifies El Niño episode, blue La Niña and green neutral conditions according with the Oceanic Niño Index (Huang et al. 2017) provided by the CPC-NOAA. Note: the warm event in 2016 corresponds to one registered in August when La Niña had already developed.
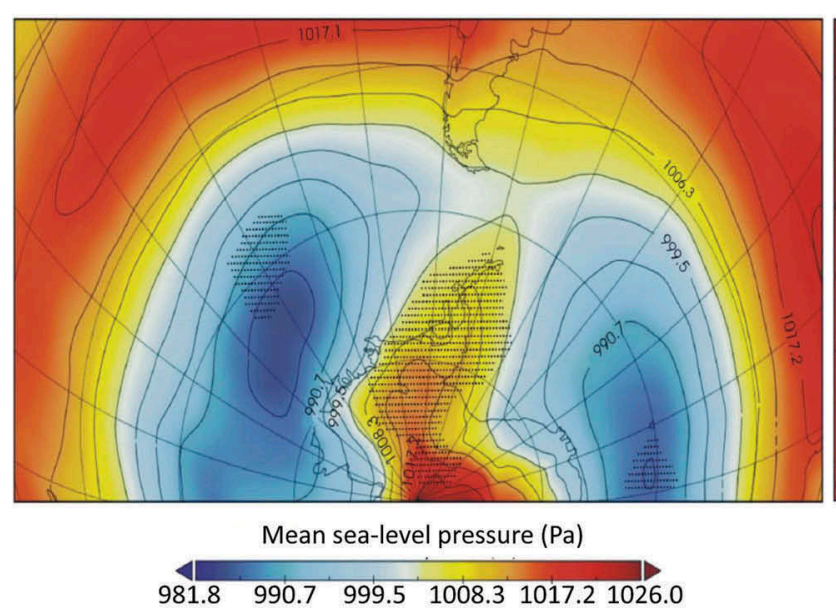

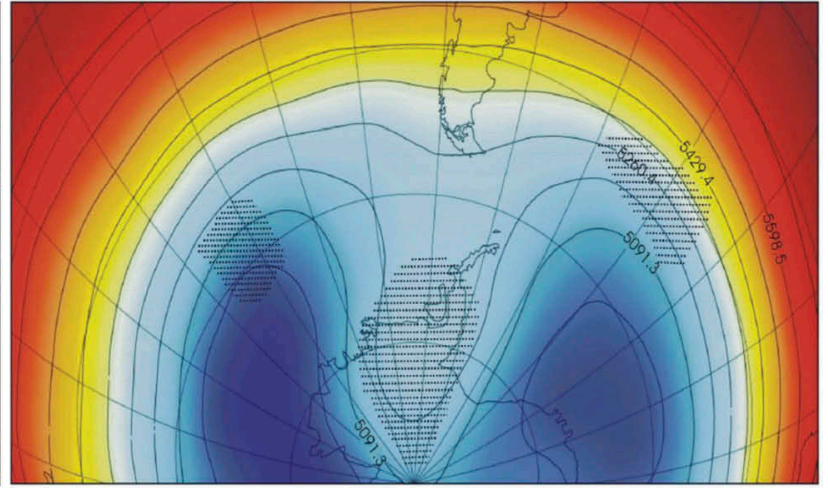

Geopotential $\left(\mathrm{m}^{2} \mathrm{~S}^{-2}\right)$

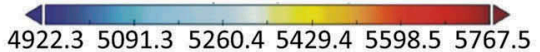

Figure 9. Mean composite analyses of the sea-level pressure (top) and 500-hPa (bottom) fields for all cases of extreme positive gpm events near $\mathrm{PH}$, constructed using the ERAin. Shaded areas are regions where the anomalies are statistically significant at the $95 \%$ confidence level.

during the 5-7 December event, i.e., on with a daily average above $-4.3^{\circ} \mathrm{C}$, then the number of years with extreme warm events decreases to three, with one occurring during an El Niño (1997) and the other two with neutral conditions (1984 and 1993).

The AAO is also a dominant mode of extratropical atmospheric circulation in the Southern Hemisphere (Zhang et al. 2013). During the last 50 years the AAO -also known as Southern Annular Mode (Thomson \& Wallace 2000)- has shown a positive trend mainly in summer (December-February); however, it also has an intra-seasonal and interannual variability as well as inter-daily variability fluctuating between positive and negative values. During the negative phase, the AAO shows low (high) pressure anomalies in the midlatitudes (in high latitudes and Antarctica) resulting in a northward displacement and a weaker circumpolar westerly wind belt than the average (Goodwin et al. 2016). This also means that the circumpolar trough is weakened because of the northward displacement of the storm track, steering the synoptic-scale cyclonic activity away from West Antarctica towards South America (Goodwin et al. 2016). When the AAO is in the negative phase, sea-level pressure anomalies take place in the south-eastern South Pacific Ocean, resulting in a weaker Amundsen Sea Low (Turner et al. 2013). Figure 10 shows the average AAO index for each extreme positive gpm events with the corresponding geopotential height at $500 \mathrm{hPa}$. The AAO data were obtained from the CPC-NOAA (ftp://ftp.cpc.ncep. noaa.gov/cwlinks/). Almost all the events (46 out of 47) occurred with negative AAO index, where around $74 \%$ (35 out 47 ) of the positive gpm events occurred for 


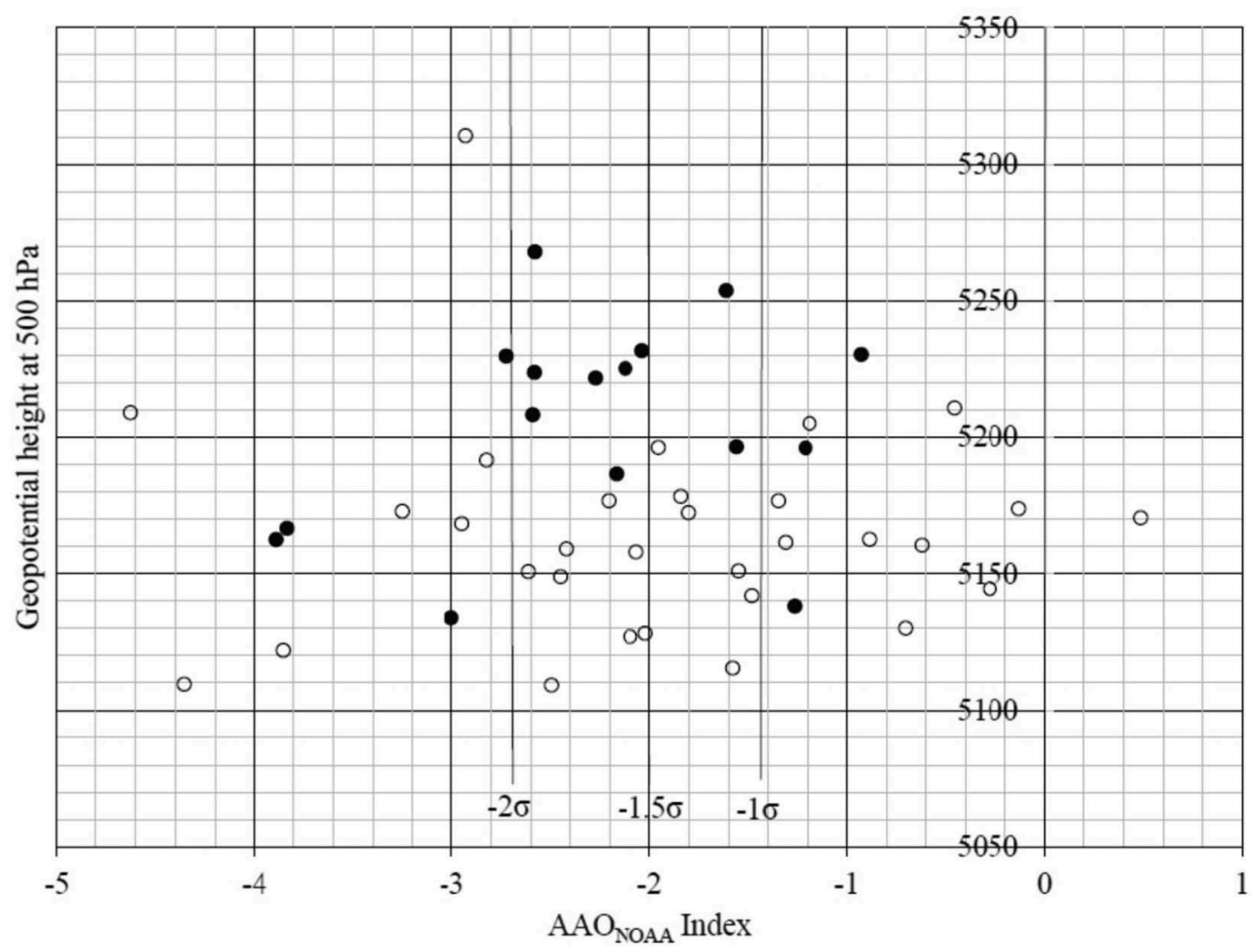

Figure 10. Scatter plot of the extreme warm events near PH during the 1979-2016 period, given by the 500-hPa geopotential anomalies and the AAO index obtained from the CPC-NOAA. Filled (unfilled) circles are events that occurred during the November-February (March-October) period.

AAO values below -1 SD. Also, around $84 \%$ (13 out of 16) of the late spring and summer events took place with the AAO index below $-1 \mathrm{SD}$. The fact that most of the events occurred in the negative phase suggests that more favourable atmospheric conditions for midtropospheric ridge development occur towards the interior of West Antarctica, near PH. During the positive AAO less blocking ridges could develop or the amplitude of a ridge-trough pattern could be weaker.

\section{Conclusion}

In summary, even though the warming event observed in 1997 occurred during a strong El Niño, warm events may occur during any phase of ENSO at $\mathrm{PH}$ and the surrounding region. For these events to occur a passing ridge or blocking ridge builds up around the Antarctic Peninsula and Ellsworth Land. Therefore, as for the melt episode observed on the Ross Ice Shelf in January 2016, no conclusive link can be drawn between warm events in the interior of Antarctica and El Niño. On the other hand, most of the warm $\mathrm{PH}$ events occurred during the negative phase of the AAO, suggesting a link with the atmospheric circulation associated with the AAO.

The mid-tropospheric ridge sets up an atmospheric circulation that allows warm maritime air advection from either the Bellingshausen or Amundsen seas towards the interior of West Antarctica. The atmospheric anticyclonic circulation near the surface can also support the south-westerly downslope airflow, which can adiabatically warm by the foehn effect while descending the northern slope (lee side) of the $\mathrm{PH}$. However, in the case analysed here it seems that warming due to foehn effect is not relevant; rather, synoptic-scale advection the predominant one.

On the other hand, the case of the highest air temperature recorded at the AWS at Byrd of $1.3^{\circ} \mathrm{C}$ at 00 UTC 7 January 2005, which is about 15 degrees warmer than the January average $\left(-13.9^{\circ} \mathrm{C}\right)$ for the $1981-$ 2016 period, along with records air temperature of $3.0^{\circ} \mathrm{C}$ at $\mathrm{PH}$ and $3.3^{\circ} \mathrm{C}$ at Union Glacier, are examples of extreme warm events that occurred far from the coastal-low areas in the interior of Antarctica but below the $2500 \mathrm{~m}$ elevation region defined by the World Meteorological Organization. This might suggest that a third subregion is needed for station records located far beyond the permanent influence of the ocean environment but below $2500 \mathrm{~m}$ a.s.l.

\section{Acknowledgements}

This work was part of the meteorological activities in Antarctica supported by the Dirección Meteorológica de Chile. The Chilean Air Force provided the logistic support. Dr Gino Casassa took the pictures displayed in Fig. 3. I also appreciate 
the contributions of anonymous reviewers and Dr John Cassano that significantly improved the original manuscript.

\section{Disclosure statement}

No potential conflict of interest was reported by the author.

\section{Funding}

This work was completed by the support of the Comision Nacional de Investigación Científica y Tecnológica, Fondecyt Project no. 1151034.

\section{References}

Bennartz R., Shupe M.D., Turner D., Walden V.P., Steffemn K., Cox C.J., Kulie M.S., Miller N.B. \& Pettersen C. 2012. July 2012 Greenland melt extent enhanced by low-level liquid clouds. Nature 496, 83-96.

Bintanja R. 1999. On the glaciological, meteorological, and climatological significance of Antarctic blue ice areas. Review of Geophysics 37, 337-359.

Boskurt D., Rondanelli R., Marin J.C. \& Garreaud R.D. 2018. Foehn event triggered by an atmospheric river underlies record-setting temperature along continental Antarctica. Journal of Geophysical ResearchAtmospheres 123, 3871-3892.

Carrasco J.F. 1996. Aspectos meteorológicos observados en Patriot Hills, 1995. (Meteorological observations at Patriot Hills, 1995.) Boletín Antártico Chileno 15, 14.

Carrasco J.F. 1997. Informe meteorológico de la Campaña "Aurora Austral 1996". (Meteorological report of the Aurora Austral 1996 campaign.) Boletín Antártico Chileno 16, 16-17.

Carrasco J.F. 1999. Condiciones atmosféricas en Patriot Hills durante la campaña del 8 noviembre al 4 diciembre de 1995. (Atmospheric conditions at Patriot Hills during the campaign of 8 November to 4 December.) Serie Científica INACH 49, 37-50.

Casassa G., Brecher H., Cárdenas C. \& Rivera A. 1998. State of balance of the Antarctic Ice Sheet at Patriot Hills. Annals of Glaciology 27, 130-134.

Dee D.P., Uppala S.M., Simmons A.J., Berrisford P., Poli P., Kobayashi S., Andrae U., Balmaseda M.A., Balsamo G., Bauer P., Bechtold P., Beljaars A.C.M., van de Berg L., Bidlot J., Bormann B., Delsol C., Dragani R., Fuentes M., Geer A.J., Haimberger L., Healy S.B., Hersbach H., Hólm E.V., Isaksen L., Kallberg P., Kohler M., Matricardi M., McNally A.P., Monge-Sanz B.M., Morcrette J.-J., Park B.-K., Peubey C., de Rosnay P., Tavalato C., Thépaut J.-N. \& Vitart F. 2011. The ERA-Interim reanalysis: configuration and performance of the data assimilation system. Quarterly Journal of the Meteorological Society 137, 553-597.

Goodwin B.P., Moslley-Thompson E., Wilson A.B., Porter S.E. \& Sierra-Hernandez R. 2016. Accumulation variability in the Antarctic Peninsula: the role of large-scale atmospheric oscillation and their interactions. Journal of Climate 29, 2579-2596.

Hoffman M.J., Fountain A.G. \& Liston G.E. 2008. Surface energy balance and melt thresholds over 11 years at Taylor
Glacier, Antarctica. Journal of Geophysical Research-Earth Surface 113, F04014, doi: 10.1029/2008JF001029.

Huang B., Thorne P.W., Banzon V.F., Boyer T., Chepurin G., Lawrimore J.H., Menne T.M., Vose R.S. \& Zhang H.-M. 2017. Extended Reconstructed Sea Surface Temperature, version 5 (ERSSTv5): upgrades, validations, and intercomparisons. Journal of Climate 30, 8179-8205.

Nicolas J.P., Vogelmann A.M., Ryan C., Scott R.C., Wilson A. B., Cadeddu M.P., Bromwich D.H., Verlinde J., Lubin D., Lynn M., Russell L.M., Jenkinson C., Heath H., Powers H. H., Ryczek M., Stone G. \& Wille J.D. 2017. January 2016 extensive summer melt in West Antarctica favoured by strong El Niño. Nature Communications 8, article no. 15799, doi: 10.1038/ncomms15799.

Parish T.R. \& Bromwich D.H. 1987. The surface windfield over the Antarctic ice sheets. Nature 328, 51-54.

Parish T.R. \& Cassano J.J. 2003. The role of katabatic winds on the Antarctic surface wind regime. Monthly Weather Review 131, 317-333.

Renwick J.A. 1998. ENSO-related variability in the frequency of South Pacific blocking. Monthly Weather Review 126, 3117-3123.

Senese A., Maugeri M., Vullermoz F., Smiraglia C. \& Diolaiuti G. 2014. Using daily air temperature thresholds to evaluate snow melting occurrence and amount on alpine glaciers by T-index models: the case study of the Forni Glacier (Italy). The Cryosphere 8, 1921-1933.

Skansi M.d.L.M., King J., Lazzara M.A., Cerveny R.S., Stella L., Solomon S., Jones P., Bromwich D., Renwick J., Burt C.C., Peterson T.C., Brunet M., Driouech F., Vose R. \& Krahenbuhl D. 2017. Evaluating highest temperature extremes in the Antarctic. Eos 98, 18-33.

Speirs J.C., McGowan H.A, Steinhoff D.F., \& Bromwich D. H. 2013. Regional climate variability driven by foehn winds in the McMurdo Dry Valleys, Antarctica. International Journal of Climatology 33, 945-958.

Steinhoff D.F., Bromwich D.H. \& Monoghan A. 2013. Dynamics of the foehn mechanism in the McMurdo Dry Valleys of Antarctica from Polar WRF. Quarterly Journal of the Meteorological Society 139, 1615-1631.

Swithinbank C.S.M. 1987. Ice runways in the Heritage Range, Antarctica. Annals of Glaciology 14, 211-215.

Thomson D.W.J. \& Wallace J.M. 2000. Annular modes in the extratropical circulation. Part I: month-to-month variability. Journal of Climate 13, 1000-1016.

Turner J. 2004. Review: the El Niño-Southern Oscillation and Antarctica. International Journal of Climatology 24, $1-31$.

Turner J., Phillips T., Hosking J.S., Marshall G.J. \& Orr A. 2013. The Amundsen Sea Low. International Journal of Climatology 33, 1818-1829.

van den Broeke M., Bus C., Ettema J. \& Smeets P. 2010. Temperature thresholds for degree-day modelling of Greenland ice sheet melt rates. Geophysical Research Letters 37, L18501, doi: 10.1029/2010GL044123.

Yuan X. 2004. ENSO-related impacts on Antarctic sea ice: a synthesis of phenomenon and mechanisms. Antarctic Science 16, 415-425.

Zhang Z., Gong D., Kim S., Mao R. \& Yang J. 2013. Is the Antarctic oscillation trend during the recent decades unusual? Antarctic Science 26, 445-451. 